American Journal of Applied Sciences 7 (12): 1558-1561, 2010

ISSN 1546-9239

(C) 2010 Science Publications

\title{
Mitigation Voltage Sag in Power System by Static Synchronous Compensator
}

\author{
Prechanon Kumkratug \\ Division of Electrical Engineering, Faculty of Engineering at Si Racha, \\ Kasetsart University, 199 M.6, Tungsukhla, Si Racha, Chonburi, 20230, Thailand
}

\begin{abstract}
Problem statement: The disturbance in power system is unavoidable situation. It cause in voltage sag in power system. Approach: This study applied the STATCOM to mitigate voltage of the system. The mathematical model of power system equipped with a STATCOM is systematically derived. The presented mathematical model is shown how it effects on voltage sag improvement. The simulation results are tested on a Single Machine Infinite bus. The proposed method is equipped in sample system with severe disturbance. The variation voltage of the system without and with a STATCOM is plotted and compared. Results: It was found that the system without a STATCOM has high voltage variation especially voltage sags whereas with a STATCOM the system voltage has small voltage sages. Conclusion: From the simulation results, the STATCOM can mitigate voltage of power system.
\end{abstract}

Key words: Power system, transient stability, Flexible AC Transmission (FACTS), synchronous, Unified Power Flow Controller (UPFC), thyristor controlled phase shifter, High Voltage Direct Current (HVDC), leakage reactance, control strategy, equivalent, complex power, voltage sag, Single Machine Infinite Bus (SMIB)

\section{INTRODUCTION}

Voltage sag is one of the most important power qualities in customer aspects. It is unavoidable in power system with fault or disturbance (Hochgraph and Lasseter, 1998; Uzunovic et al., 1997; Al-Rawi at al., 2007; Hingorani and Gyugyi, 2000; Song and Johns, 1999). The application of advanced power electronic such as Flexible AC Transmission (FACTS) and High Voltage Direct Current (HVDC) system is the one possible way to mitigate voltage sag. There are various forms of FACTS devices such as Static Synchronous Series Compensator (SSSC), Static Synchronous Compensator (STATCOM), Unified Power Flow Controller (UPFC) (Ahmad and Al-Husban, 2009; Barbuy et al., 2009; Kumkratug, 2010; Magaji and Msutafa, 2009; Hannan et al., 2009; Zarate-Minano et al., 2010).

A Static Synchronous Compensator (STATCOM) is a member of the FACTS family that is connected in shunt with system. The STATCOM consists of a solid state voltage source converter with GTO thyristor switches or other high performance of semi-conductor and transformer. The STATCOM can electrically mimic reactor and capacitor by injecting a shunt current in quadrature with the line voltage. The reactive power (or current) of the STATCOM can be adjusted by controlling the magnitude and phase angle of the output voltage of the shunt converter (Ahmad and AlHusban, 2009)

This study applied the STATCOM to mitigate voltage of the system. The mathematical model of power system equipped with a STATCOM is systematically derived. The presented mathematical model is shown how it effects on voltage sag improvement. The simulation results are tested on a Single Machine Infinite bus system.

\section{MATERIALS AND METHODS}

Mathematical model: Figure 1a shows the single line diagram of Single Machine Infinite Bus (SMIB) system without a STATCOM and the corresponding equivalent circuit is shown in Fig. 1b. Here $X_{1}$ is the equivalent reactance between the machine internal bus and the bus $m$ and $X_{2}$ is the equivalent reactance between bus $m$ and the infinite bus. The generator is represented by a constant voltage source (E') behind transient reactance $\left(X_{d}^{\prime}\right)$.

The active power balance at bus $m$ is given by:

$\mathrm{P}_{\mathrm{R}}=\mathrm{P}_{\mathrm{S}}$

Here:

$P_{R}=\frac{E^{\prime} V_{m 0}}{X_{1}} \sin \left(\delta-\theta_{m 0}\right)$ 


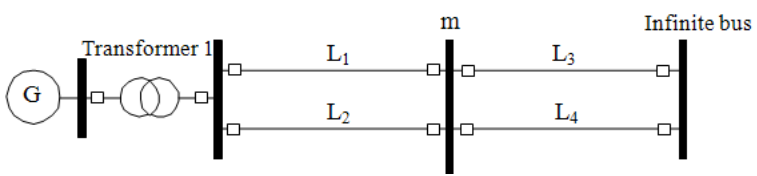

(a)

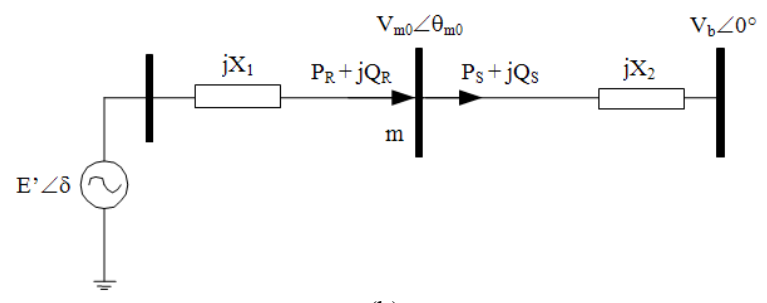

(b)

Fig. 1: Single machine infinite bus system schematic diagram (b) equivalent circuit

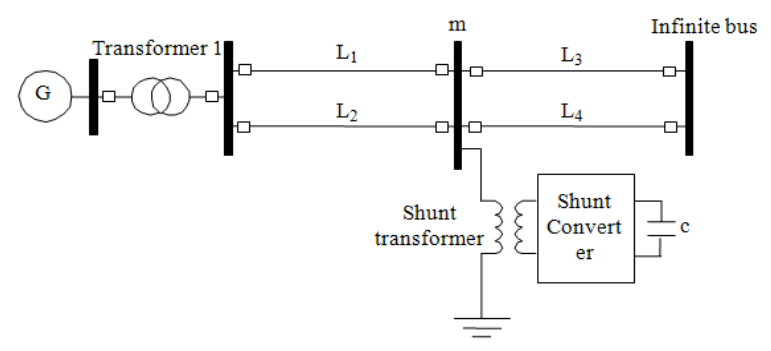

(a)

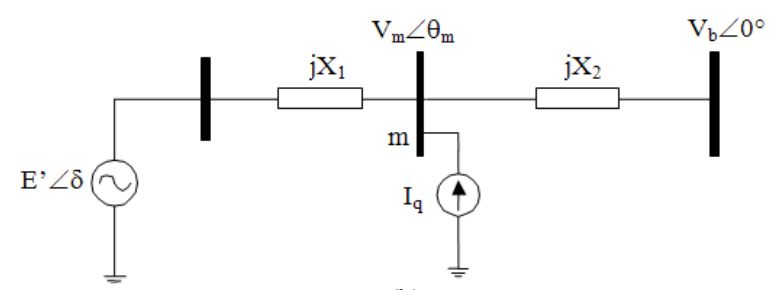

(b)

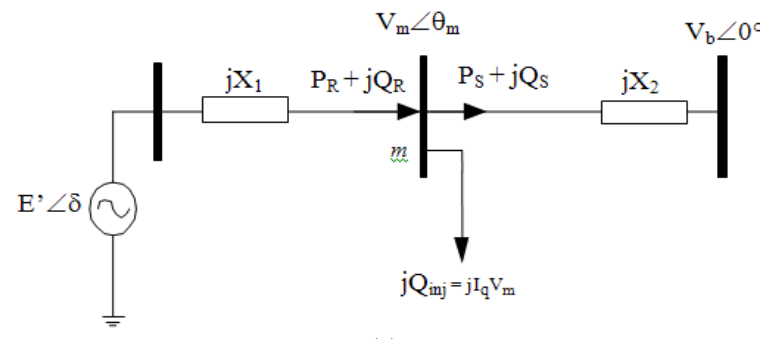

(c)

Fig. 2: Single machine infinite bus system with a STATCOM (a) schematic diagram (b) equivalent circuit of system with a STATCOM represented by a current injection model (c) equivalent circuit of system with a STATCOM represented by a load injection model and:

$$
\mathrm{P}_{\mathrm{S}}=\frac{\mathrm{V}_{\mathrm{m} 0} \mathrm{~V}_{\mathrm{b}}}{\mathrm{X}_{2}} \sin \left(\theta_{\mathrm{m} 0}\right)
$$

After some mathematical manipulations of Eq. 1Eq. 3, the voltage angle at bus $\mathrm{m}$ of the system without STATCOM is given by:

$\theta_{\mathrm{m} 0}=\tan ^{-1}\left(\frac{\mathrm{E}^{\prime} \mathrm{X}_{2} \sin \delta}{\mathrm{E}^{\prime} \mathrm{X}_{2}}\right)$

The reactive power balance at bus $m$ is given by:

$\mathrm{Q}_{\mathrm{R}}=\mathrm{Q}_{\mathrm{S}}$

Here:

$\mathrm{Q}_{\mathrm{R}}=\frac{\mathrm{E}^{\prime} \mathrm{V}_{\mathrm{m} 0}}{\mathrm{X}_{1}} \cos \left(\delta-\theta_{\mathrm{m} 0}\right)-\frac{\mathrm{V}_{\mathrm{m} 0}^{2}}{\mathrm{X}_{1}}$

and:

$\mathrm{Q}_{\mathrm{S}}=\frac{\mathrm{V}_{\mathrm{m} 0}^{2}}{\mathrm{X}_{2}}-\frac{\mathrm{V}_{\mathrm{m} 0} \mathrm{~V}_{\mathrm{b}}}{\mathrm{X}_{2}} \cos \theta_{\mathrm{m} 0}$

After some mathematical manipulations of Eq. 5-7, the voltage magnitude at bus $m$ of the system without STATCOM is:

$$
\mathrm{V}_{\mathrm{m} 0}=\frac{\mathrm{E}^{\prime} \mathrm{X}_{2} \cos \left(\delta-\theta_{\mathrm{m} 0}\right)+\mathrm{X}_{1} \mathrm{~V}_{\mathrm{b}} \cos \theta_{\mathrm{m} 0}}{\mathrm{X}_{1}+\mathrm{X}_{2}}
$$

It can observe from the Fig. $1 \mathrm{~b}$ and $2 \mathrm{a}-\mathrm{c}$ that the STACOM doesn't affect on the active power balance and then the voltage angle equation at bus doesn't change written by:

$$
\theta_{\mathrm{m}}=\theta_{\mathrm{m} 0}=\tan ^{-1}\left(\frac{\mathrm{E}^{\prime} \mathrm{X}_{2} \sin \delta}{\mathrm{E}^{\prime} \mathrm{X}_{2}}\right)
$$

However, the STATCOM affects on reactive power balance given by:

$\mathrm{Q}_{\mathrm{R}}=\mathrm{Q}_{\mathrm{S}}+\mathrm{Q}_{\mathrm{inj}}$

Here:

$\mathrm{Q}_{\mathrm{inj}}=-\mathrm{V}_{\mathrm{m}} \mathrm{I}_{\mathrm{q}}$ 
Am. J. Applied Sci., 7 (12): 1558-1561, 2010

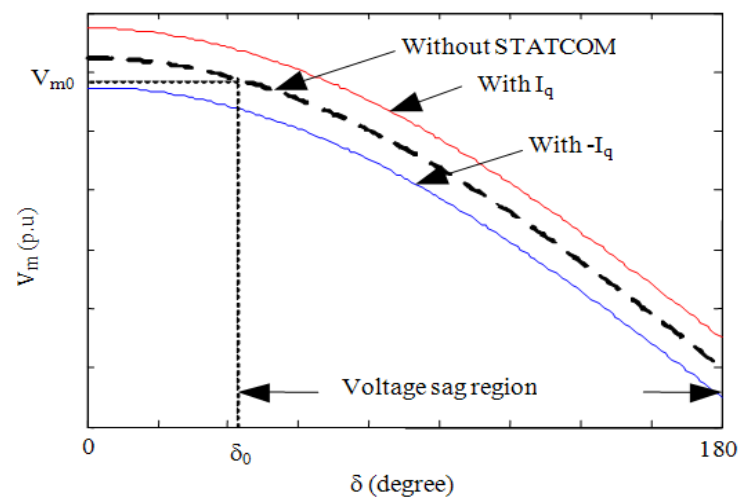

Fig. $3: \mathrm{V}_{\mathrm{m}}-\delta$ curve

After some mathematical manipulations, the voltage magnitude at bus $\mathrm{m}$ of the system with a STACOM is given by:

$$
\mathrm{V}_{\mathrm{m}}=\frac{\mathrm{E}^{\prime} \mathrm{X}_{2} \cos \left(\delta-\theta_{\mathrm{m}}\right)+\mathrm{X}_{1} \mathrm{~V}_{\mathrm{b}} \cos \theta_{\mathrm{m}}+\mathrm{X}_{1} \mathrm{X}_{2} \mathrm{I}_{\mathrm{q}}}{\mathrm{X}_{1}+\mathrm{X}_{2}}
$$

From Eq. 8 and 12, the voltage magnitude at bus $\mathrm{m}$ of the system with a STATCOM is given by:

$\mathrm{V}_{\mathrm{m}}=\mathrm{V}_{\mathrm{m} 0}+\mathrm{CI}_{\mathrm{q}}$

Here:

$\mathrm{C}=\mathrm{X}_{1} \mathrm{X}_{2} /\left(\mathrm{X}_{1}+\mathrm{X}_{2}\right)$

Voltage sag and improvement: It can be seen from Eq. 9,12 and 13 that the voltage magnitude at bus $\mathrm{m}$ $\left(\mathrm{V}_{\mathrm{m}}\right)$ depends on machine angle $(\delta)$ and current injection of STATCOM $\left(\mathrm{I}_{\mathrm{q}}\right)$. Figure 3 shows the $\mathrm{V}_{\mathrm{m}}-\delta$ curve. At steady state, the operating points of the system are $\mathrm{V}_{\mathrm{m} 0}$ and $\delta_{0}$, respectively. When the system is subject to disturbance, the $\delta$ significantly increases and thus the voltage dramatically decreases. The $\mathrm{V}_{\mathrm{m}}$ can be improved by injecting the current $I_{q}$ in positive sign as can be seen in Fig. 3. Our objective is to maintain $\mathrm{V}_{\mathrm{m}}$ is at $\mathrm{V}_{\mathrm{m} 0}$. The control strategy of $\mathrm{I}_{\mathrm{q}}$ is given by:

$$
\mathrm{I}_{\mathrm{q}}=\mathrm{K}\left(\mathrm{V}_{\mathrm{m}}-\mathrm{V}_{\mathrm{m} 0}\right)
$$

\section{RESULTS}

The presented mathematical model and control strategy is used to study the effect of STATCOM on voltage sag improvement. The diagram of the system is shown in the Fig. 4 and the system parameters are:

$\mathrm{M}=3.5, \mathrm{X}_{\mathrm{t}}=0.15, \mathrm{X}_{\mathrm{d}}^{\prime}=0.3, \mathrm{X}_{\mathrm{L} 1}=0.5, \mathrm{X}_{\mathrm{L} 2}=0.5, \mathrm{X}_{\mathrm{L} 3}=$ $0.5, \mathrm{X}_{\mathrm{L} 4}=0.5, \mathrm{P}_{\mathrm{m}}=0.9, \mathrm{Vb}=1 \mathrm{pu}$

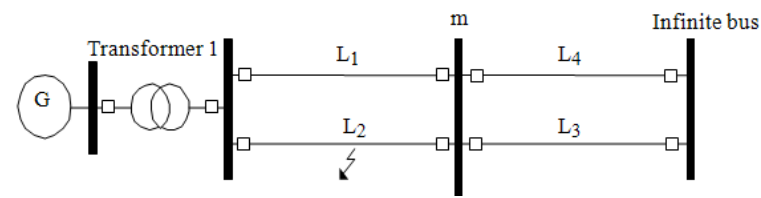

Fig. 4: Sample system

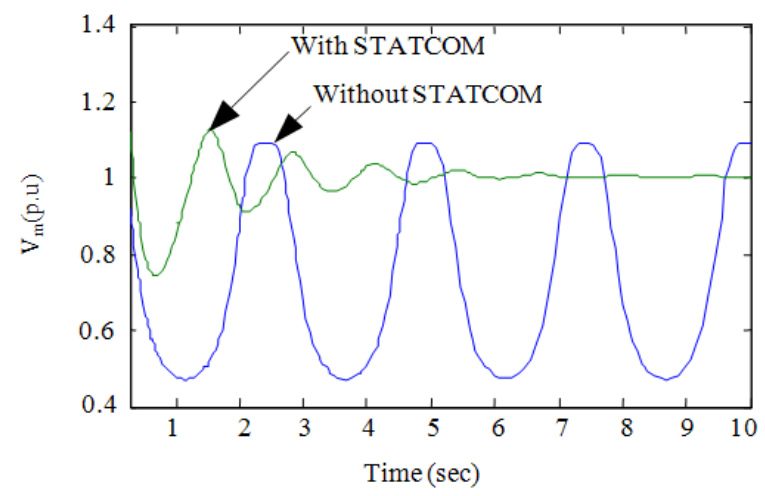

Fig. 5: Comparison of the voltage profile for system without and with a STATCOM

It is considered that a three phase self clearing fault appears at middle of the line 2 and the fault is cleared by opening the circuit breaker at the both ends. Figure 5 shows the comparison of the voltage sag of the system without and with a STATCOM.

\section{DISCUSSION}

It can be obviously seen from the Fig. 5 that the voltage of system without a STATCOM is continuously osculation. The voltage magnitude of the system at steady state is round 1 p.u. where at the post fault the minimum voltage magnitude is decreased to 0.5 p.u. This may cause in the damage of the electrical equipment. However, with a STATCOM a minimum voltage is around $0.8 \mathrm{pu}$. Moreover it can return to the stable equilibrium by $5 \mathrm{sec}$.

\section{CONCLUSION}

This study applies the Static Synchronous Compensator (STATCOM) to mitigate the voltage sag in power system. The mathematical model of the STACOM is systematically derived. The presented mathematical model has shown that the system voltage can be regulated by the STATCOM. The simulation results are tested on Single Machine Infinite Bus 
(SMIB) system. From the simulation results, it indicates that the STATCOM can mitigate the voltage sag of power system.

\section{REFERENCES}

Ahmad and N. Al-Husban, 2009. An eigenstructure assignment for a static synchronous compensator. Am. J. Eng. Applied Sci., 2: 812-816. http://www.scipub.org/fulltext/ajeas/ajeas114552.pdf

Al-Rawi, N.M., A. Anwar and A.M. Abdul-Majeed, 2007. Computer aided transient stability analysis. J. Comput. $\quad$ Sci., $\quad 3$ : 149-153. http://www.scipub.org/fulltext/jcs/jcs33149153.pdf

Barbuy, H.S., A. Rocco, L.A.P. Fernandes and G.C. Guimarães, 2009. Voltage collapse risk associated to under-voltage capacitive compensation in electric power system operation. Am. J. Applied Sci., 6: 646-651. http://www.scipub.org/fulltext/ajas/ajas64646651.pdf

Hannan, M.A., A. Mohamed, A. Hussian and M.A. Dabbay, 2009. Development of the unified series-shunt compensator for power quality mitigation. Am. J. Applied Sci., 6: 978-986. http://www.scipub.org/fulltext/ajas/ajas65978986.pdf

Hingorani, N.G. and L. Gyugyi, 2000. Understanding FACTS, Concepts, and Technology of Flexible AC Transmission Systems. 1st Edn., IEEE Press, Piscataway, NJ, pp: 432. ISBN: 0780334558
Hochgraph, C. and R.H. Lasseter, 1998. STATCOM controls for operation with unbalanced voltages. IEEE Trans. Power Delivery, 13: 538-544. DOI: 10.1109/61.660926

Kumkratug, P., 2010. Fast decoupled power flow for power system with high voltage direct current transmission system. Am. J. of Applied Sci., 7: 1115-1117. http://www.scipub.org/fulltext/ajas/ajas7811151117.pdf

Magaji, N. and M.W. Mustafa, 2009. Optimal thyristor control series neuro-controller for damping oscillations. J. Comput. Sci., 5: 983-990. http://www.scipub.org/fulltext/jcs/jcs512983990.pdf

Song, Y.H. and A.T. Johns, 1999. Flexible AC Transmission Systems (FACTS). 1st Edn., Institution of Engineering and Technology, IEE, London, ISBN: 0-85296-771-3, pp: 596.

Uzunovic, E., C.A. Canizares and J. Reeve, 1997. Fundamental frequency model of static synchronous compensator. http://en.scientificcommons.org/42367365

Zarate-Minano, R., T. Van Custsem, F., Milano, A.J. Conejo, 2010. Securing transient stability using time domain simulations within an optimal power flow. IEEE Trans. Power Sys., 5: 243-253. DOI: 10.1109/TPWRS.2009.203069 